\title{
MULTI-CORRELATION BETWEEN NEMATODE COMMUNITIES AND ENVIRONMENTAL VARIABLES IN MANGROVE-SHRIMP PONDS, CA MAU PROVINCE, SOUTHERN VIETNAM
}

\author{
Thai Thanh Tran', Nguyen Thi My Yen', Hoang Nghia Son ${ }^{1,2}$, Ngo Xuan Quang ${ }^{1,2, *}$ \\ ${ }^{1}$ Institute of Tropical Biology, VAST, Vietnam \\ ${ }^{2}$ Graduate University of Science and Technology, VAST, Vietnam
}

Received 26 October 2019, accepted 28 July 2020

\begin{abstract}
Multi-correlation between bio-indices of nematode communities and ecological parameters in mangrove-shrimp farming ponds in Tam Giang commune, Nam Can District, Ca Mau Province, Vietnam were investigated. In which, diversities of nematode communities and several environmental variables in eight ponds were considered to process. Our findings underlined the high diversity of nematode communities in mangrove-shrimp farming ponds compared to other mangrove habitats. Nematode diversities provided more oppotunity in natural food for shrimp. Single correlation analyses showed that the species richness index correlated significantly to three variables (salinity, total organic carbon, and total nitrogen), the Margalef diversity index correlated to two variables (salinity, total organic carbon), and the expected number of species for 50 individuals index correlated with one variable (salinity). Results of multi-correlation analyses between the nematode bio-indices and the environmental variables were completely different from those of single-correlation analyses. In multi-correlation analyses, the species richness and the Margalef diversity index correlated to two variables (salinity, total organic carbon), Pielou's evenness index and Hill indices correlated with dissolved oxygen, also the Hurlbert index correlated to total organic carbon. Hence, it is necessary to pay attention to the impact of complex interactions between the multi-environmental variables and nematode communities. This research aims to explain the differences between single- and multi-correlation for evaluation of the effects of environmental factors on nematodes as well as aquatic organisms.
\end{abstract}

Keywords: Aquaculture, aquatic ecology, benthic fauna, chemical water diversity, mangroves, sediment.

Citation: Thai Thanh Tran, Nguyen Thi My Yen, Hoang Nghia Son, Ngo Xuan Quang, 2020. Multi-correlation between nematode communities and environmental variables in mangrove-shrimp ponds, Ca Mau Province, Southern Vietnam. Academia Journal of Biology, 42(3): 15-29. https://doi.org/10.15625/2615-9023/v42n3.14546.

*Corresponding author email: ngoxuanq@gmail.com

(O2020 Vietnam Academy of Science and Technology (VAST) 


\section{INTRODUCTION}

The largest remaining area of mangrove forest in Vietnam is situated in coastal provinces and river mouths of Mekong Delta which covers approximately 100,000 ha. The $\mathrm{Ca}$ Mau Province has the largest area of mangroves with over 58,285 ha, followed by Tra Vinh (8,582 ha), Ben Tre (7,153 ha), Bac Lieu (4,142 ha), and Soc Trang (2,943 ha) (Truong \& Do, 2018). Ca Mau mangroves are very rich in biodiversity, containing 98 species of mangroves (e.g. Rhizophora apiculata, Kandelia obovata, Sonneratia caseolaris and Avicennia alba) with $R$. apiculata being the most abundant (Vu, 2004). Studies on aquatic fauna indicated that $\mathrm{Ca}$ Mau mangroves have a fauna of 46 species of fish, 25 species of shrimps and 57 species of birds including 17 migratory species (Phan \& Hoang, 1993). Also, the Ca Mau mangroves had 28 species of mammals belonging to 12 families, 5 species are listed in Vietnam's Red Book, 1 species in the IUCN's Red Book (Ca Mau Province Portal, 2013).

In 2017-2018, several studies were conducted to determine the biodiversity of aquatic organisms in mangrove-shrimp farming ponds in Nam Can District, Ca Mau Province. The phytoplankton communities contained 64 species belonging to four groups namely bluegreen algae, diatom, green algae and dinoflagellates (Pham et al., 2017). Macrofauna communities contained 22 species of 15 families belonging to 5 classes: Polychaeta, Oligochaeta, Crustacea, Gastropoda, and Bivalvia of 3 phyla: Annelida, Arthropoda and Mollusca (Tran et al., 2017b). Tran et al. (2017c) studied meiofauna assemblages in mangrove-shrimp farming ponds in $\mathrm{Ca} \mathrm{Mau}$ Province and recorded 15 major taxa, including Nematoda, Copepoda, Turbellaria, Polychaeta, Oligochaeta, Amphipoda, Tardigrada, Ostracoda, Rotifera, Sarcomastigophora, Kinorhyncha, Isopoda, Halacaroidea, Thermosbaenacea, and Cladocera.

The nematode communities consisted of 75 genera belonging to 24 families and 7 orders. The density was quite high, ranging from $221 \pm$ 122 (inds $\left./ 10 \mathrm{~cm}^{2}\right)$ to $7254 \pm 5454$ (inds/10 $\mathrm{cm}^{2}$ ) and the Shannon-Wiener index expressed high diversity, ranging from $2.35 \pm 1.02$ to 3.61 \pm 0.24 (Tran et al., 2018c). Thus, nematode communities of $\mathrm{Ca}$ Mau mangrove-shrimp farming ponds (CMMSFP) could be characterized by high biodiversity. Nematode communities play a vital role in benthic ecosystems processes. They form a crucial component in benthic food webs with trophic links between microfauna and larger fauna.

Main food sources of nematode communities are organic detritus, bacteria and benthic diatoms. In turn, nematode communities can provide food for a number of predators such as juvenile fish, shellfishes, and also other nematodes (Liu et al., 2014). Chong \& Sasekumar (1981) found that the white prawn Penaeus merguiensis is a carnivore that feeds largely on nematodes and other small organisms. Thus, nematode communities can make a substantial contribution as a food source for shrimps in the CMMSFP. Also, nematode communities play a vital role in the flow of nutrients, materials, and energy in benthic and aquatic ecosystems. Several studies showed that mineralization of organic matter is enhanced and stimulated by the presence of nematode communities (Semprucci et al., 2013).

Ensuring suitable environmental conditions for nematode communities is essential to maintain their diversities and densities, and to provide sufficient food sources for shrimp in the CMMSFP. To optimize this environment, interaction between nematodes and environmental variables should be analyzed. It is well known that densities, diversities, distribution, and functional properties of meiofauna (including nematodes) could be affected by a number of environmental variables such as salinity, temperature, hydrodynamics, granulometrics, dissolved oxygenation level, and food availability (Ingels et al., 2011; Cai et al., 2012; Ngo et al., 2013a; Zeppilli et al., 2013; Górska et al., 2014). According to Tran et al. (2018a), diversities of meiofauna communities in shrimp farm in the CMMSFP showed significant positive correlation with 
dissolved oxygen but significant negative correlation with total organic carbon and total nitrogen. Furthermore, abundances of the genera Sabatieria and Terschellingia showed significant positive correlation with total organic carbon, total nitrogen, and depth. In contrast, Desmodora, Halalaimus and Ptycholaimellus showed negative correlation with organic enrichment (Tran et al., 2018c). However, these correlations were based on single-correlation analyses, which were designed to determine the impact of a single quantitative environmental factor on nematode characteristics. While studies and reviews on the single-correlation between environmental variables and nematodes are increasingly common, to date, few studies have assessed the multi-correlation between environmental variables and the nematode characteristics. Differences between single- vs multi-correlation analyses and the effects of environmental variables on the nematode characteristics needs to be investigated.

In this study, we provide (i) additional information on the nematode bio-indices in the CMMSFP and (ii) explore multi-factorial interactions between the nematode bio-indices and the environmental variables. Results obtained in this study are valuable for understanding biodiversities of benthic nematofauna and their complex interactions with environmental variables in mangrove forest.

\section{MATERIALS AND METHODS}

\section{Study location}

The present study was carried out in eight different stations in the CMMSFPs (P1-P8) situated in the Tam Giang Commune, Nam Can District, Ca Mau Province (Fig. 1). Detailed information about the study area has been described by Tran et al. (2018c).

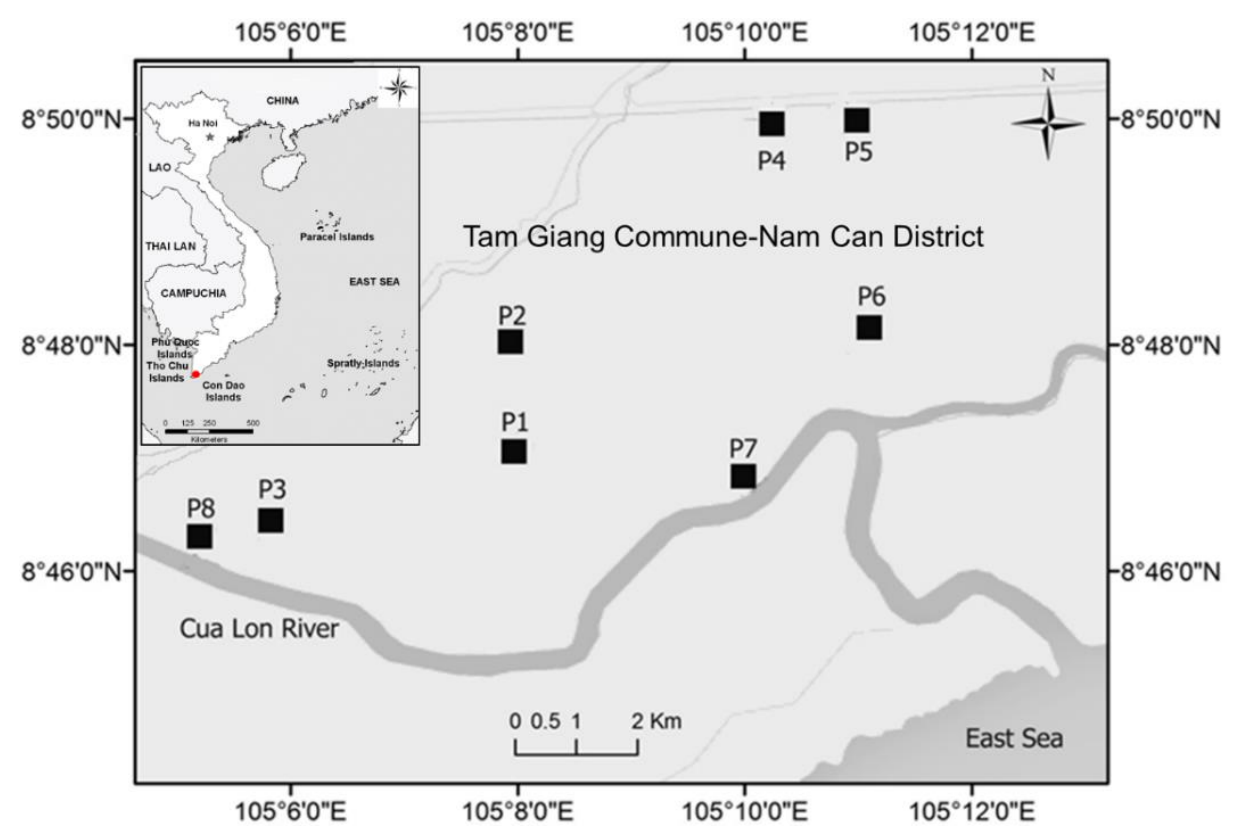

Figure 1. Map and ordinations of sampling stations in eight mangrove-shrimp farming ponds in Tam Giang commune, Nam Can District, Ca Mau Province

\section{Sampling and laboratory activities}

Nematode communities in the CMMSFP were investigated in three periods: March-dry season, July-transient season and November- rainy season of 2015. Nematode samples were collected in triplicate using $10 \mathrm{~cm}^{2}$ cores with $3.5 \mathrm{~cm}$ in diameter, pushed in the sediment at least $10 \mathrm{~cm}$ deep. Only samples with clear overlying water with sediment depth up to 10 
$\mathrm{cm}$ were retained. Sediment samples were then preserved in $7 \%$ neutralized formaldehyde (heated to $60{ }^{\circ} \mathrm{C}$ ). In the laboratory, nematode specimens were extracted from the sediment using a $1-\mathrm{mm}$ mesh upper sieve and a $38 \mu \mathrm{m}$ mesh lower sieve. The flotation technique using LudoxTM50 (specific gravity of 1.18) was applied to separate the specimens from the sediment (Vincx, 1996). To facilitate the sorting and counting of nematodes under a stereomicroscope, the samples were further stained with $1 \%$ Rose Bengal solution. About 100 nematodes from each sample (if the sample consists of less than 100, all nematodes in that sample) were picked out randomly and specimens were processed and mounted on permanent slides for identification (De Grisse, 1969). Nematodes were identified to genus level according to Platt \& Warwick (1983, 1988), Warwick et al. (1988), Zullini (2005), Nguyen (2007) and the NEMYS database of the Marine Biology Section, Ghent University, Belgium (Bezerra et al., 2018) (www.nemys.ugent.be).

Furthermore, data and methods of sampling of sediment characteristics such as depth (Dep, cm), dissolved oxygen (DO, $\mathrm{mg} / \mathrm{l})$, salinity (Sal, \%o), $\mathrm{pH}, \mathrm{Fe}^{2+}(\mathrm{mg} / 100 \mathrm{~g})$, $\mathrm{Fe}^{3+}(\mathrm{mg} / 100 \mathrm{~g})$, total organic carbon (TOC, $\%$ ), and total nitrogen (TN, \%) followed those described by Tran et al. (2018a).

\section{Data analyses}

All data of nematode communities was presented as an average \pm standard deviation. The following bio-indices: genera richness (S), Margalef diversity index (d), Pielou's evenness index $(\mathrm{J}$ '), the expected number of species at Hurlbert's index (ES(50)), and Hill indices $\left(\mathrm{N}_{1}, \mathrm{~N}_{2}\right.$, and $\left.\mathrm{N}_{\text {inf }}\right)$ were used as biodiversity measures for nematode communities. The software Primer v.6.1.6 was used to calculate the diversity indices.

Non-parametric Spearman's rank correlation coefficient was used to identify the correlation between the environmental variables and the nematode bio-indices $(\mathrm{S}, \mathrm{d}$, $\mathrm{J}$, ES(50), $\mathrm{N}_{1}, \mathrm{~N}_{2}$, and $\mathrm{N}_{\mathrm{inf}}$ ). A regression procedure was applied to construct a statistical model describing the multi-correlation of the multi-quantitative variables (Dep, Sal, $\mathrm{pH}$, $\mathrm{Fe}^{2+}, \mathrm{Fe}^{3+}, \mathrm{TOC}$, and $\mathrm{TN}$ ) on a dependent variable (nematode bio-indices). Moreover, a two-way ANOVA test was carried out to compare the attributes of the nematode communities between seasons and ponds. Tukey's honestly significant difference (Tukey HSD) multiple range test was used when a significant difference $(\mathrm{p}<0.05)$ was detected in two-way ANOVA tests. All statistical analysis was performed using the software Statgraphic Centurion XV version 15.1.02.

\section{RESULTS}

\section{The nematode bio-indices in the mangrove- shrimp farming pond}

Composition and densities of nematode communities in CMMSFP have been described in details by Tran et al. (2018c). The lowest biodiversity value was observed at the dry season in $\mathrm{P} 1$ and $\mathrm{P} 2$, whereas the highest biodiversity value was observed at the dry season in other ponds (except for Hill indices in P3, P4, and P6). The nematode biodiversity decreased gradually from the dry season to the rainy season (except for $\operatorname{ES}(50)$ in P4, Hill indices in P3, P4, and P6). More specifically, the average species richness index $(\mathrm{S})$ ranged from $13.33 \pm 0.62(\mathrm{P} 1)$ to $21.33 \pm 0.77$ (P6) in the dry season, from $16.33 \pm 0.83(\mathrm{P} 7)$ to $21.00 \pm 0.76(\mathrm{P} 6)$ in the transient season, and from $11.33 \pm 0.65(\mathrm{P} 7)$ to $17.33 \pm 0.82$ (P6) in the rainy season (Fig. 2A). The diversity of nematode communities measured by the Margalef diversity index (d) ranged from $2.35 \pm 1.13(\mathrm{P} 1)$ to $4.32 \pm 0.32$ (P6) in the dry season, ranging from $3.20 \pm$ $1.46(\mathrm{P} 7)$ to $4.25 \pm 0.66(\mathrm{P} 6)$ in the transient season and from $2.20 \pm 1.50(\mathrm{P} 7)$ to $3.65 \pm$ 0.48 (P6) in the rainy season (Fig. 2B). The Pielou's evenness index $(\mathrm{J}$ ') ranged from 0.62 \pm 0.18 (P1) to $0.83 \pm 0.06(\mathrm{P} 5)$ in the dry season but was higher in the transient and rainy seasons, ranging from $0.71 \pm 0.05(\mathrm{P} 7)$ to $0.85 \pm 0.15(\mathrm{P} 3)$ and from $0.65 \pm 0.16(\mathrm{P} 7)$ to $0.85 \pm 0.03$ (P3), respectively (Fig. $2 \mathrm{C}$ ). The ES(50) index showed a trend similar to 
other indices ( $\mathrm{S}, \mathrm{d}, \mathrm{J}$ ' index). $\mathrm{ES}(50)$ value was highest in the dry season (except for P1 and $\mathrm{P} 2$ ), and gradually decreased from the dry season to the rainy season (except for P6)
(Fig. 2D). Regarding Hill indices, P1, P2, P3, P4, P5, and P6 showed the highest value during the sampling period, whereas P7 showed the lowest value (Figs. 2E-2D).

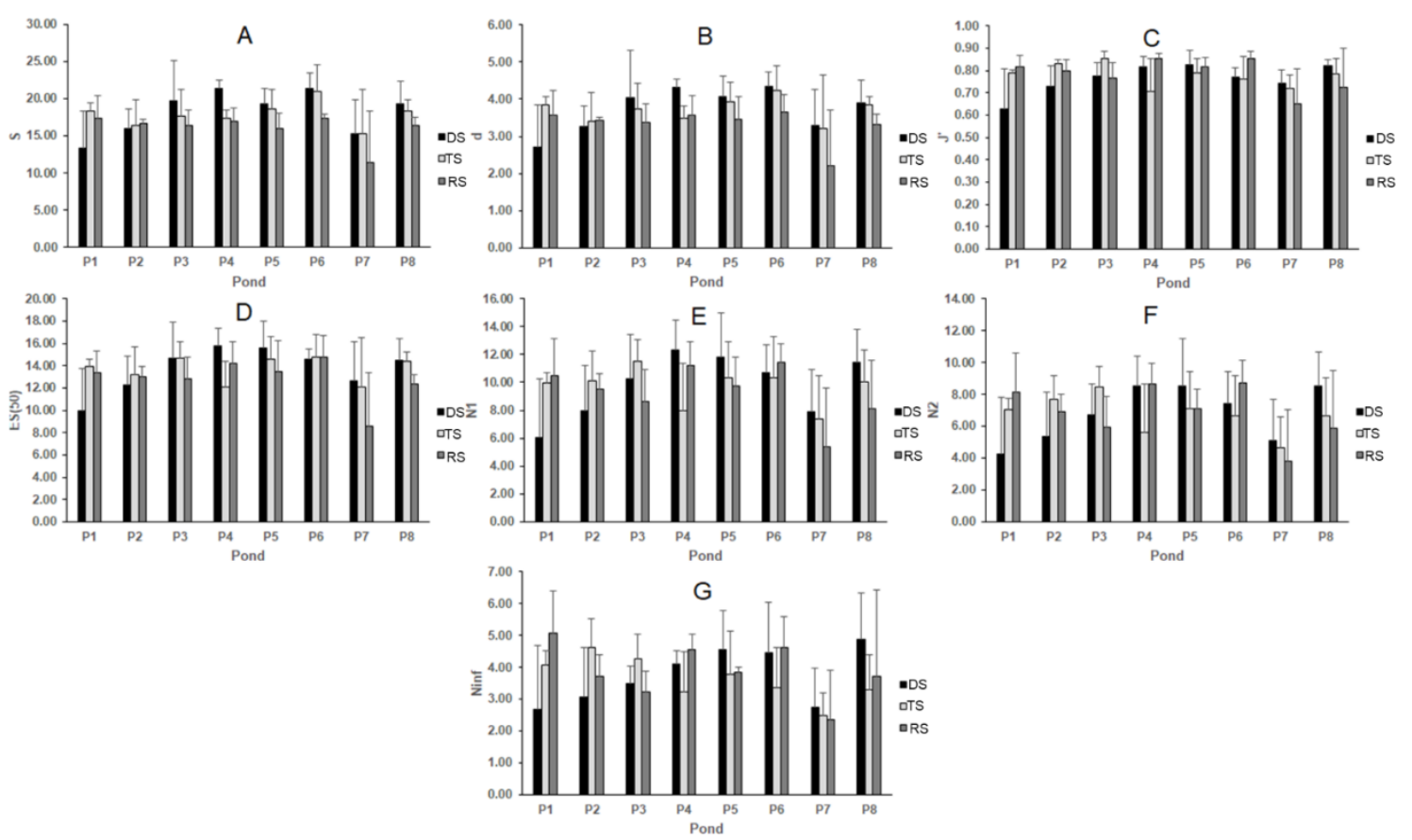

Figure 2. Average and standard deviation of different nematode bio-indices for eight different ponds (P1-P8) during the dry season (DS), transient season (TS), and the rainy season (RS)

Two-way ANOVA test was carried out to compare the biodiversity indices $(\mathrm{S}, \mathrm{d}, \mathrm{J}$, ES(50) and Hill indices) between seasons and ponds. Results indicated that seasonal factors and the factor interaction between seasons and ponds (season*pond) have no statistically significant effect on any indexes. In contrast, the pond factor showed statistically significant effect on $\mathrm{S}, \mathrm{d}, \mathrm{ES}(50)$, and $\mathrm{N}_{1}$ index (Table 1).

Table 1. The $\mathrm{p}$ value of the two - way ANOVA for the nematode bio-indices

\begin{tabular}{|l|c|c|c|c|c|c|c|}
\hline & $\mathrm{S}$ & $\mathrm{d}$ & $\mathrm{J}$ & $\mathrm{ES}(50)$ & $\mathrm{N}_{1}$ & $\mathrm{~N}_{2}$ & $\mathrm{~N}_{\text {inf }}$ \\
\hline Season & 0.10 & 0.14 & 0.68 & 0.36 & 0.78 & 0.98 & 0.87 \\
\hline Pond & $\mathbf{0 . 0 1}$ & $\mathbf{0 . 0 2}$ & 0.17 & $\mathbf{0 . 0 2}$ & $\mathbf{0 . 0 2}$ & 0.06 & 0.09 \\
\hline Season*Pond & 0.62 & 0.61 & 0.08 & 0.31 & 0.17 & 0.22 & 0.27 \\
\hline
\end{tabular}

Tukey HSD tests with a multiple comparison procedure were used to check whether the nematode bio-indices were significantly different between seasons/ponds. With this method, there was a $5.0 \%$ risk of calling one or more pairs significantly different when their actual difference equaled 0. Figs. 3-4 showed the means of the nematode bio-indices with their 95\% Tukey HSD intervals. For each index, there was no statistically significant difference between seasons (Fig. 3). Compared to the biodiversity indices between ponds, there were significant differences for $\mathrm{S}, \mathrm{d}, \mathrm{ES}(50)$, and $\mathrm{N}_{1}$ indices between P6 and P7 (Fig. 4). 


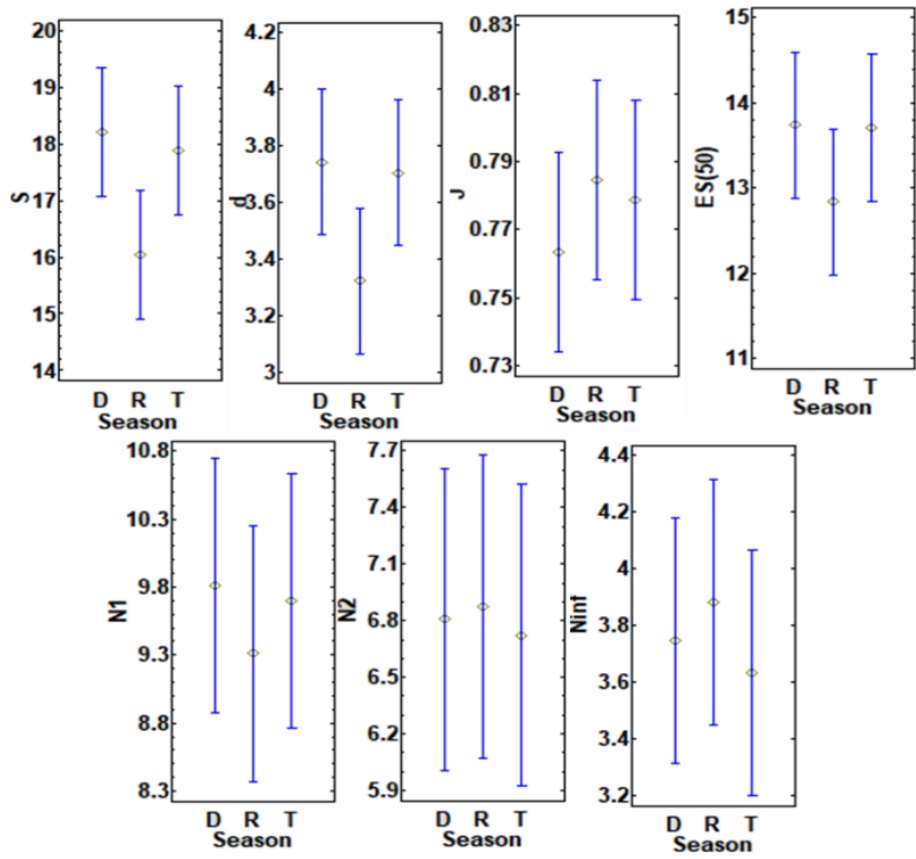

Figure 3. Tukey HSD multiple range tests for nematode community attributes (factor seasons)
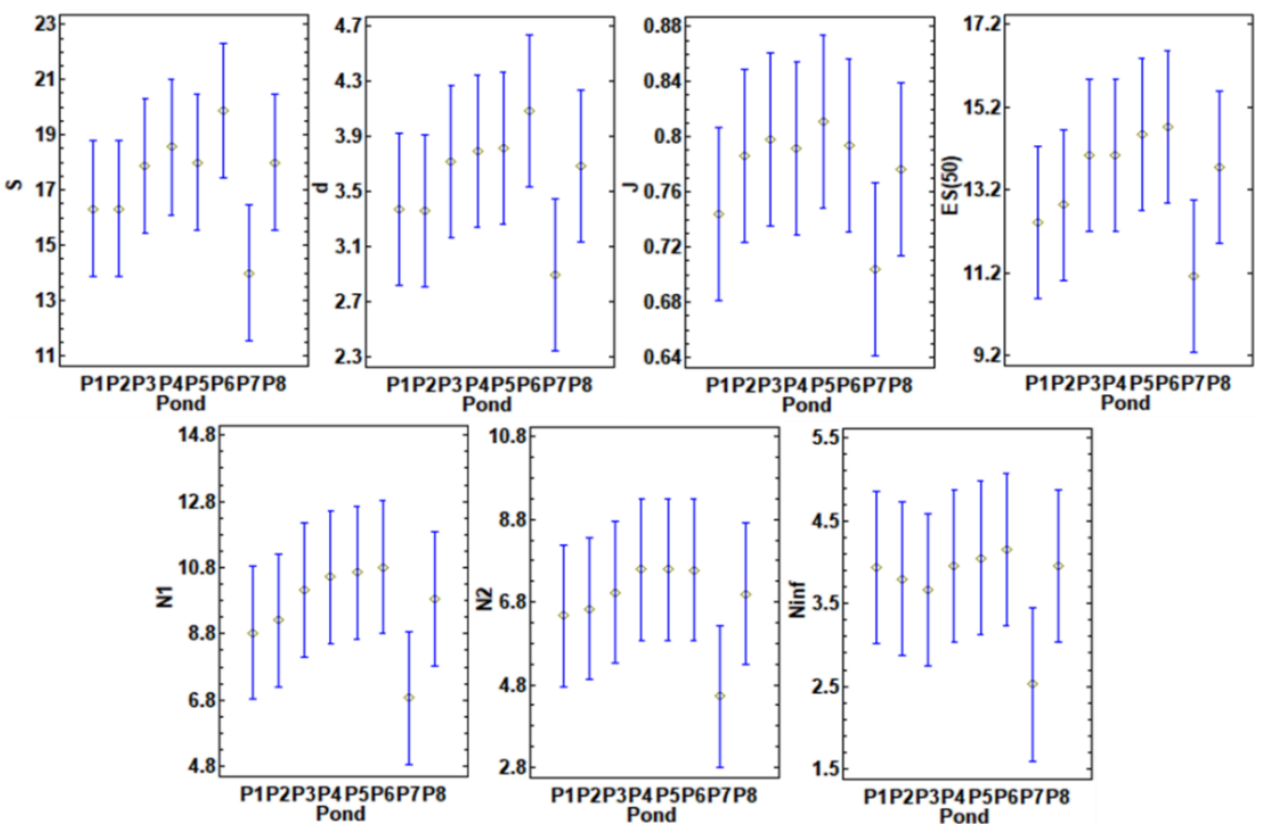

Figure 4. Tukey HSD multiple range tests for the nematode bio-indices (factor ponds)

Correlations communities variables

In order to investigate a possible significant correlation between the environmental variables with the characteristics of nematode communities, Spearman rank correlation analysis was conducted between the environmental data and the nematode bio-indices. Results 
confirmed that three variables (Sal, TOC, and $\mathrm{TN}$ ) correlated significantly with three bioindices of the nematode communities $(\mathrm{S}, \mathrm{d}$, and ES(50)). Specifically, salinity was significantly positively correlated with $\mathrm{S}$ and $\mathrm{d}$ index ( $\mathrm{r}=0.31$ and 0.29 , respectively). By contrast, TOC showed negative correlations with $\mathrm{S}, \mathrm{d}$, and $\mathrm{ES}(50)(\mathrm{r}=-0.32,-0.32$, and 0.26 , respectively); $\mathrm{TN}$ also showed negative correlation with $\mathrm{S}(\mathrm{r}=-0.25)$. Overall, both organic enrichment variables have a negative effect on the nematode bio-indices (Table 2).

Table 2. The $\mathrm{r}$ and $\mathrm{p}$-value of Spearman rank correlation between the environmental variables and the nematode bio-indices $(\mathrm{n}=72)$ (p-values $<0.05$ indicated with bold values)

\begin{tabular}{|c|c|c|c|c|c|c|c|c|}
\hline EnV. variables & & $\mathrm{S}$ & $\mathrm{d}$ & $\mathrm{J}^{\prime}$ & $\mathrm{ES}(50)$ & $\mathrm{N}_{1}$ & $\mathrm{~N}_{2}$ & $\mathrm{~N}_{\text {inf }}$ \\
\hline \multirow{2}{*}{ Dept. } & $\mathrm{r}$ & -0.21 & -0.16 & 0.11 & -0.07 & 0.00 & 0.04 & 0.06 \\
\cline { 2 - 9 } & $\mathrm{p}$ & 0.08 & 0.17 & 0.37 & 0.54 & 1.00 & 0.75 & 0.59 \\
\hline \multirow{2}{*}{$\mathrm{DO}$} & $\mathrm{r}$ & -0.15 & -0.12 & -0.15 & -0.08 & -0.14 & -0.19 & -0.19 \\
\cline { 2 - 9 } & $\mathrm{p}$ & 0.20 & 0.32 & 0.20 & 0.48 & 0.23 & 0.12 & 0.11 \\
\hline \multirow{2}{*}{ Sal } & $\mathrm{r}$ & 0.31 & 0.29 & -0.14 & 0.20 & 0.09 & 0.00 & -0.01 \\
\cline { 2 - 9 } & $\mathrm{p}$ & $\mathbf{0 . 0 1}$ & $\mathbf{0 . 0 1}$ & 0.23 & 0.10 & 0.44 & 0.98 & 0.94 \\
\hline \multirow{2}{*}{$\mathrm{pH}$} & $\mathrm{r}$ & -0.12 & -0.11 & 0.09 & -0.05 & 0.00 & 0.04 & 0.09 \\
\cline { 2 - 9 } & $\mathrm{p}$ & 0.32 & 0.35 & 0.44 & 0.68 & 0.99 & 0.73 & 0.44 \\
\hline \multirow{2}{*}{$\mathrm{Fe}^{2+}$} & $\mathrm{r}$ & -0.05 & -0.06 & 0.03 & -0.05 & -0.03 & -0.01 & 0.01 \\
\cline { 2 - 9 } & $\mathrm{p}$ & 0.68 & 0.62 & 0.80 & 0.65 & 0.81 & 0.95 & 0.92 \\
\hline \multirow{2}{*}{$\mathrm{Fe}^{3+}$} & $\mathrm{r}$ & -0.17 & -0.12 & 0.19 & 0.02 & 0.07 & 0.11 & 0.07 \\
\cline { 2 - 9 } & $\mathrm{p}$ & 0.16 & 0.29 & 0.12 & 0.87 & 0.57 & 0.37 & 0.54 \\
\hline \multirow{2}{*}{$\mathrm{TOC}$} & $\mathrm{r}$ & -0.32 & -0.32 & -0.11 & -0.26 & -0.21 & -0.19 & -0.22 \\
\cline { 2 - 9 } & $\mathrm{p}$ & $\mathbf{0 . 0 1}$ & $\mathbf{0 . 0 1}$ & 0.37 & $\mathbf{0 . 0 3}$ & 0.08 & 0.11 & 0.06 \\
\hline \multirow{2}{*}{$\mathrm{TN}$} & $\mathrm{r}$ & -0.25 & -0.23 & -0.13 & -0.16 & -0.17 & -0.16 & -0.15 \\
\cline { 2 - 8 } & $\mathrm{p}$ & $\mathbf{0 . 0 4}$ & 0.06 & 0.29 & 0.19 & 0.15 & 0.19 & 0.22 \\
\hline
\end{tabular}

\section{Multi-interactions communities and \\ between nematode the environmental variables}

Overall, multi-interaction analyses showed that each nematode bio-index was at most affected by independent variables, e.g. $\mathrm{S}$ and d were influenced by Sal and TOC. Other bio-indices were affected by only one variable such as DO, except for ES(50). A multiple linear regression model was built to describe the relationship between $\mathrm{S}$ and 8 independent environmental variables (Table 3). The equation of the fitted model was $\mathrm{S}=16.82+$ $0.17 *$ Sal $-0.97 *$ TOC. Since the p-value in the ANOVA test was 0.0002 , there is a statistically significant relationship between the variables at a $95.0 \%$ confidence level.

The R-Squared statistic indicated that the model fitted explains $22.5 \%$ of the variability in $\mathrm{S}$ index. The standard error of the estimate
(SE Est.) showed the error range of the residuals to be 3.19. The average value of the residuals (the mean absolute error-MAE) was 2.36. The Durbin-Watson (DW) statistic tests the residuals to see if there are any significant correlation based on the order in which they occur in the data file. Since the pvalue of 0.53 was $>0.05$, there is no indication of serial autocorrelation in the residuals at a $95.0 \%$ confidence level. Figure $5 \mathrm{~A}$ showed a plot of the fitted model of $\mathrm{S}$ index with salinity and TOC. The multiple regression model of $\mathrm{d}$ and the environmental variables (Fig. 5B) were interpreted similarly. The other indices including J', ES(50), Hill indices were affected only by DO. Therefore, a linear regression model was used to describe the relationship between these indices and 8 independent variables. For example, the equation of the fitted model between $\mathrm{J}$ ' and DO was $\mathrm{J}$ ' $=0.86-0.01 * \mathrm{DO}$ 
$(\mathrm{p}=0.03<0.05)$. Moreover, the R-Squared statistic showed that the model as fitted explains $6.4 \%$ of the variability in J'. The standard error of the estimate indicated that the range of the eorror of the residuals was 0.08 . Furthermore, the average value of the residuals (MAE) was 0.06 . Since the p-value $(0.38)$ of D-W statistic test was $>0.05$, there was no proof of serial autocorrelation in the residuals at the $95.0 \%$ Confidential level (Table 3). The plot of the fitted linear model between $J$ ' and DO was presented in Figure 5C. In addition, the single linear regression model of remaining indices and environmental variables was similarly interpreted.

Table 3. Multiple regression coefficients and results of fitting the regression model to describe the relationship between the nematode communities and the environmental variables

\begin{tabular}{|l|l|c|c|c|c|c|}
\hline \multicolumn{1}{|c|}{ Nema.-En.V } & \multicolumn{1}{|c|}{ Multi-regression model } & $\mathrm{R}^{2}$ & $\begin{array}{c}\mathrm{SE} \\
\text { Est. }\end{array}$ & MAE & $\begin{array}{c}\mathrm{D}-\mathrm{W} \\
\text { statistic }\end{array}$ & $\begin{array}{c}\mathrm{p}- \\
\text { value }\end{array}$ \\
\hline S- EnV.F. & $\mathrm{S}=16.82+0.17 * \mathrm{Sal}-0.97 * \mathrm{TOC}$ & 22.49 & 3.19 & 2.36 & 0.53 & 0.0002 \\
\hline d-EnV.F. & $\mathrm{D}=3.58+0.03 * \mathrm{Sal}-0.21 * \mathrm{TOC}$ & 21.23 & 0.70 & 0.52 & 0.70 & 0.0003 \\
\hline J'-EnV.F. & $\mathrm{J} '=0.86-0.01 * \mathrm{DO}$ & 6.38 & 0.08 & 0.06 & 0.38 & 0.03 \\
\hline ES(50)-EnV.F. & $\mathrm{ES}(50)=16.29-0.68 * \mathrm{TOC}$ & 13.51 & 2.44 & 1.88 & 0.63 & 0.001 \\
\hline $\mathrm{N}_{1}$-EnV.F. & $\mathrm{N}_{1}=13.36-0.50 * \mathrm{DO}$ & 11.58 & 2.72 & 2.23 & 0.55 & 0.003 \\
\hline $\mathrm{N}_{2}$-EnV.F. & $\mathrm{N}_{2}=9.92-0.41 * \mathrm{DO}$ & 11.46 & 2.25 & 1.88 & 0.61 & 0.003 \\
\hline $\mathrm{N}_{\text {inf }}$-EnV.F. & $\mathrm{N}_{\text {inf }}=5.36-0.21 * \mathrm{DO}$ & 10.63 & 1.21 & 0.94 & 0.60 & 0.005 \\
\hline
\end{tabular}

Notes: Environmental variables (En.V:), standard error of the estimate (SE Est:); mean absolute error (MAE), Durbin-Watson statistic (D-W statistic).
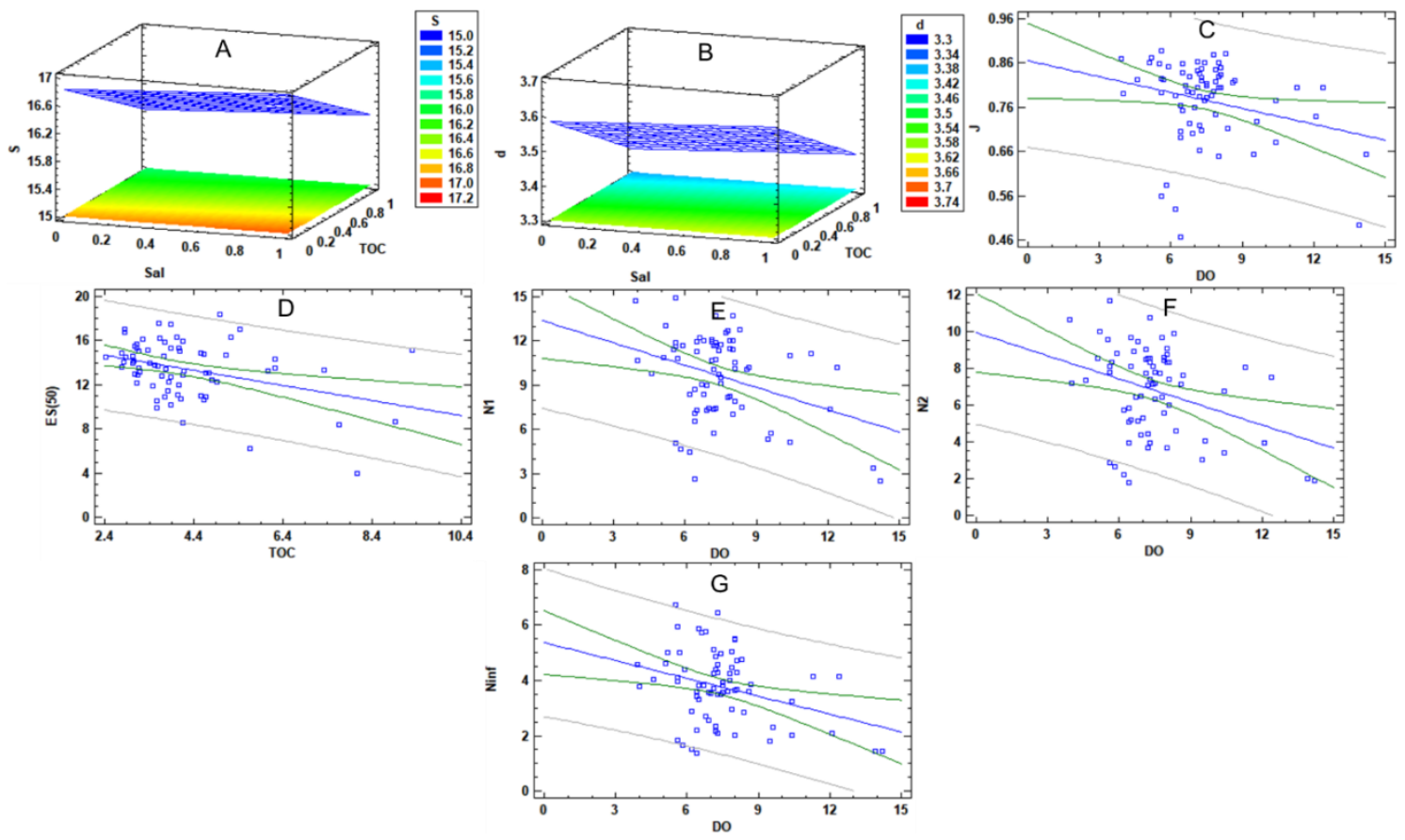

Figure 5. A plot of fitted (A) Multi-regression model between S and Sal/TOC, (B) Multiregression model between $\mathrm{d}$ and Sal/TOC, (C-G) Simple regression model between J' and DO, ES(50)-TOC, Hill indices-DO, respectively 


\section{DISCUSSION}

Comparison of nematode bio-indices in $\mathrm{Ca}$ Mau mangrove-shrimp farming ponds with other similar habitats and its impact

The recent study by Tran et al. (2018c) is one of the first investigations on nematode biodiversities in the CMMSFP. Therefore, we used their biodiversity data (Tran et al. $2018 \mathrm{c}$ ) in combination with results of the present study to better understand the diversity of nematode communities in the CMMSFP and to compare them with similar studies on MSFPs around the world. The composition and densities of nematode communities in some ponds were different leading to differences in bio-indices. However, seasonal factors do not often significantly affect bio-indices of nematode communities because the tropical climate allows for continuous cycle of reproduction of nematodes (Ngo et al., 2013c).
Among biodiversity indices, H' index has been widely used for quantifying species diversity, especially for nematode diversities (Semprucci \& Balsamo, 2012). The present study estimated the nematode diversities in CMMSFP not only based on the H' index but also on other indices such as S, d, J', and Hill indices. A first attempt is made to compare our results with other data on nematode biodiversities in mangroves and mudflats (Table 4). Although the primary objectives of other studies were quite different and not completely similar methods or techniques were applied, it gives an indication of nematode diversity in our farming ponds. In general, the biodiversity of nematode communities in the CMMSFP was higher than those in a temperate intertidal mudflat in France or in the intertidal tropical mangrove mudflats in Brazil and Australia. This supports the point that $\mathrm{Ca}$ Mau's mangrove forest is characterized by high nematode diversities.

Table 4. Global data on nematode diversities from mangroves

\begin{tabular}{|l|l|c|l|}
\hline \multicolumn{1}{|c|}{ Location } & \multicolumn{1}{c|}{ Habitat } & Diversities & \multicolumn{1}{c|}{ References } \\
\hline $\begin{array}{l}\text { Ca Mau mangrove, } \\
\text { Vietnam }\end{array}$ & $\begin{array}{l}\text { Mangrove-shrimp } \\
\text { farming ponds (38- } \\
104 \mathrm{~cm} \text { in depth) }\end{array}$ & $\begin{array}{c}\mathrm{H}^{\prime}: 2.14 \pm 1.07- \\
3.61 \pm 0.24\end{array}$ & $\begin{array}{l}\text { H' from Tran et al. } \\
(2018 \mathrm{c})\end{array}$ \\
\hline $\begin{array}{l}\text { Can Gio mangrove, } \\
\text { Vietnam }\end{array}$ & Mangrove mudflat & $\mathrm{H}^{\prime}: 3.6-4.2$ & Ngo et al. (2007) \\
\hline $\begin{array}{l}\text { Hunter river and } \\
\text { Fullerton, } \\
\text { Australia }\end{array}$ & Mangrove & $\mathrm{H}^{\prime}: 1.28-2.76$ & $\begin{array}{l}\text { Hodda \& } \\
\text { Nicholas (1985) }\end{array}$ \\
\hline $\begin{array}{l}\text { Cape York } \\
\text { peninsula, Australia }\end{array}$ & $\begin{array}{l}\text { Mangrove } \\
\text { estuarine }\end{array}$ & $\mathrm{H}^{\prime}: 2.02-2.91$ & Alongi (1987) \\
\hline $\begin{array}{l}\text { Merbok, } \\
\text { Malaysia }\end{array}$ & $\begin{array}{l}\text { Rhizophora, } \\
\text { Brugiera }\end{array}$ & $\mathrm{H}^{\prime}: 2.0-3.2$ & $\begin{array}{l}\text { Gee \& } \\
\text { Somerfield (1997) }\end{array}$ \\
\hline $\begin{array}{l}\text { Victoria, SE } \\
\text { Australia }\end{array}$ & Only Avicennia & $\mathrm{H}^{\prime}: 0.558 \pm 0.084$ & Gwyther (2003) \\
\hline $\begin{array}{l}\text { Marennes-Oléron, } \\
\text { France }\end{array}$ & $\begin{array}{l}\text { Temperate } \\
\text { intertidal mudflat }\end{array}$ & $\mathrm{H}^{\prime}: 2.7-3.5$ & $\begin{array}{l}\text { Rzeznik-Orignac } \\
\text { et al. (2003) }\end{array}$ \\
\hline $\begin{array}{l}\text { Santa Catarina, } \\
\text { South Brazil }\end{array}$ & Mangrove & $\mathrm{H}^{\prime}: 2.5-3.5$ & $\begin{array}{l}\text { Netto \& Gallucci } \\
\text { (2003) }\end{array}$ \\
\hline
\end{tabular}

Globally, mangrove forests have been destroyed by coastal aquaculture, mainly shrimp farming (Hamilton, 2013; Richards \&
Friess, 2016). Integrated mangrove-shrimp farming has emerged as a part of the potential solution to protect mangrove-forest 
faced by shrimp aquaculture (Primavera et al., 2000). In 1978, integrated mangroveshrimp farming was first used in Vietnam (Hai, 2005). Nowadays, this model has been widely practiced in the country (especially in $\mathrm{Ca}$ Mau Province), considered as the best method for providing farming households with a sustainable livelihood through mangrove conservation (Ha et al., 2012). In recent years, the model has been faced with many challenges, mainly due to poor technical knowledge (Bosma et al., 2016). In CMMSFP, farmers do not apply feeds and chemicals but depend on natural recruitment of shrimp (Primavera et al., 2000). Therefore, abundances of natural food play a pivotal role in the success of the model. Presently, Penaeus monodon, commonly known as the giant tiger prawn or Asian tiger shrimp has been broadly farmed in the CMMSFP (Tho et al., 2011). The productivity of shrimp is affected by several variables including farm management, pond size, availability of natural food (zoobenthos, periphyton, phytoplankton and zooplankton), water quality (dissolved oxygen, $\mathrm{pH}$ ), and weather conditions (sunlight, rainfall) (Fitzgerald, 2000; Takashima, 2000). While El Hag (1984) reported that Penaeus monodon adults are omnivores, being able to feed on both small organisms and organic matter, nematodes and small organism are still considered to be a main food source of Penaeus monodon (Chong \& Sasekumar, 1981). The high density and biodiversity of

Single-correlation
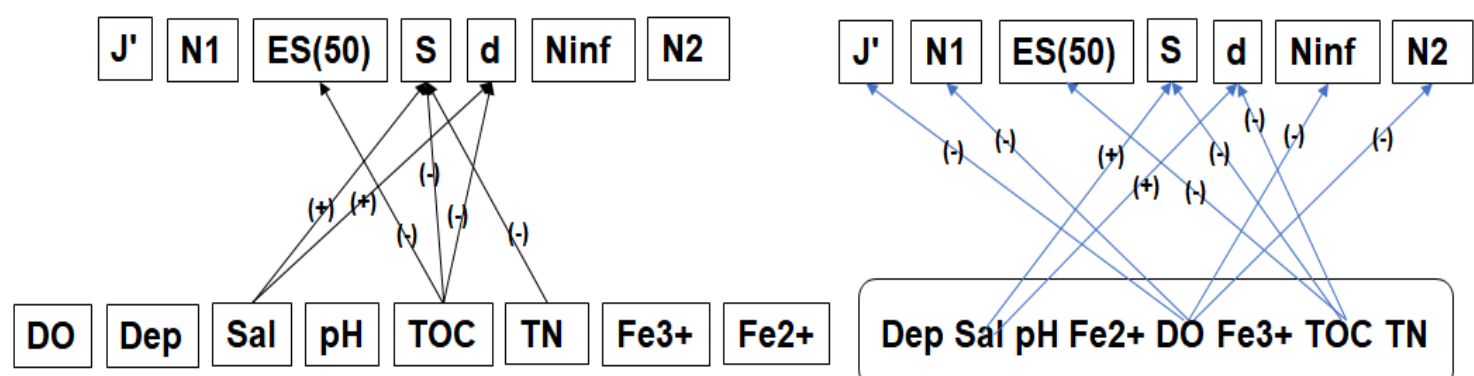

Figure 6. Single and multi-correlation between the nematode bio-indices and the environmental variables 
What variables need to be considered to raise biodiversity of nematode communities (shrimp's food source)?

Using the multi-correlation results from this study in combination with other studies (Table 5), high salinity could help promoting nematode diversities, whereas a high value of depth, $\mathrm{DO}, \mathrm{pH}$, and organic concentration (TOC, TN) could decrease the diversity. Although nematode diversities can be affected by a number of abiotic variables such as salinity, temperature, hydrodynamics, sediment grain size, oxygenation level and food availability (Ingels et al., 2011; Cai et al., 2012; Ngo et al., 2013a; Zeppilli et al., 2013; Górska et al., 2014), salinity is the most important variable. Several studies showed that salinity is one of the most common ancillary measures used in coastal and marine ecological studies to monitor drivers of benthic assemblages (Alber, 2002; Ysebaert \& Herman, 2002; Kimmel \& Roman, 2004). Moreover, salinity gradients could be more important in explaining diversity across multiple estuarine systems (Van Diggele, 2016). Therefore, salinity concentration should be considered and regularly monitored in CMMSFP. The optimal salinity for shrimp culture is about 15-25 ppt (Boyd, 1995) which is vital for pond dynamics, although shrimps can be grown in salinities varying from 4 ppt to 26 ppt. Likewise, in an earlier study, $P$. monodon favored salinity ranging from of $6.5 \mathrm{ppt}$ to $25.5 \mathrm{ppt}$ favored the growth (Das et al., 2001).

Table 5. Single-correlation between the nematode bio-indices and the environmental variables form others studies

\begin{tabular}{|c|c|c|c|c|c|}
\hline & Dep & Sal & DO & pH & TN \\
\hline $\mathrm{S}$ & $-[1]$ & $+[2,7]$ & $-[3]$ & $-[4]$ & $-[7]$ \\
\hline $\mathrm{d}$ & $-[5]$ & $+[7]$ & N.A & $-[4]$ & $-[7]$ \\
\hline $\mathrm{H}^{\prime}$ & $-[5,6]$ & $+[2]$ & $-[3]$ & $-[4]$ & $-[3]$ \\
\hline $\mathrm{ES}(50)$ & N.A & N.A & $-[3]$ & N.A & $-[7]$ \\
\hline $\mathrm{N}_{1}$ & $-[5]$ & $+[2]$ & $-[3]$ & $-[3]$ & $-[3]$ \\
\hline $\mathrm{N}_{2}$ & $-[5]$ & N.A & $-[3]$ & $-[3]$ & $-[3]$ \\
\hline $\mathrm{N}_{\text {inf }}$ & $-[5]$ & N.A & N.A & $-[3]$ & $-[3]$ \\
\hline
\end{tabular}

Notes: "+": Positive correlations; “"”: Negative correlations; N.A: Not available; [1]: Gambi et al. (2003); [2]: Tran et al. (2018b); [3]: Ngo et al. (2016); [4]: Ngo et al. (2013b); [5]: Tran et al. (2017a); [6]: Liu et al. (2015); [7]: This contribution.

\section{CONCLUSION}

This study found significant multiinteraction between nematode communities' bioindices with environmental variables in the CMMSFPs. The biodiversity of nematode communities have been considered to be high which provided more natural food for shrimps. Furthermore, the multi-correlation between the nematode bio-indices and the environmental variables produced completely different results from those of singlecorrelation analyses. Although the present study has been able to show the advantage of the multi-correlation, there are still some points we would like to address in future work, especially the complex interactions between the environmental variables and nematode communities.

\section{REFERENCES}

Alber M., 2002. A conceptual model of estuarine freshwater inflow management. Estuaries, 25(6): 1246-1261.

Alongi D. M., 1987. Inter-estuary variation and intertidal zonation of free-living nematode communities in tropical mangrove systems. Marine Ecology Progress Series, 40(1): 103-114. 
Bezerra T. N., Decraemer W., EisendleFlöckner U., Hodda M., Holovachov O., Leduc D., Miljutin D., Mokievsky V., Peña Santiago R., Sharma J., Smol N., Tchesunov A., Venekey V., Zeng Z., Vanreusel, A., 2018. Nemys: World Database of Nematodes.

Bosma R. H., Nguyen T. H., Siahainenia A. J., Tran H. T., Tran H. N., 2016. Shrimpbased livelihoods in mangrove silvoaquaculture farming systems. Reviews in Aquaculture, 8(1): 43-60.

Boyd C. E., 1995. Soil and water quality management in aquaculture ponds. INFOFISH International, 5: 29-36.

Ca Mau Province Portal, 2013. Retrieved December 1, 2013, from http://www.camau.gov.vn.

Cai L., Fu S., Yang J., Zhou X., 2012. Distribution of meiofaunal abundance in relation to environmental variables in Beibu Gulf, South China Sea. Acta Oceanologica Sinica, 31(6): 92-103.

Chong V. C. \& Sasekumar A., 1981. Food and feeding habits of the white prawn Penaeus merguiensis. Marine ecology progress series, 5(20): 185-191.

Das S. K., Saksena D. N., 2001. Farm management and water quality in relation to growth of Penaeus monodon in modified extensive shrimp culture system. Journal of Inland Fisheries Society of India, 33(2): 55-61.

De Grisse A. T., 1969. Redescription ou modification de quelques techniques utilisées dans l'étude des nématodes phytoparasitaires. Meded. Rijksfakulteit Landbouwwetenschappen, Gent 34: 351-369.

El Hag E. A., 1984. Food and food selection of the Penaeid prawn Penaeus monodon (Fabricius). In Limnology and Marine Biology in the Sudan (pp. 213-217). Springer, Dordrecht.

Fitzgerald W. J., 2000. Integrated mangrove forest and aquaculture systems in Indonesia. In Mangrove-friendly aquaculture: Proceedings of the workshop on mangrove-friendly aquaculture, eds. J.H. Primavera, L.M.B. Garcia, M.T. Castaños, and M.B. Surtida, 21-34. Iloilo City, Philippines: Organized by the Aquaculture Department, SEAFDEC.

Gambi C., Vanreusel A., Danovaro, R., 2003. Biodiversity of nematode assemblages from deep-sea sediments of the Atacama Slope and Trench (South Pacific Ocean). Deep Sea Research Part I: Oceanographic Research Papers, 50(1): 103-117.

Gee J. M., Somerfield P. J., 1997. Do mangrove diversity and leaf litter decay promote meiofaunal diversity?. Journal of experimental marine Biology and Ecology, 218(1): 13-33.

Górska B., Grzelak K., Kotwicki L., Hasemann C., Schewe I., Soltwedel T., Włodarska-Kowalczuk M., 2014. Bathymetric variations in vertical distribution patterns of meiofauna in the surface sediments of the deep Arctic ocean (HAUSGARTEN, Fram strait). Deep Sea Research Part I: Oceanographic Research Papers, 91: 36-49.

Gwyther J., 2003. Nematode assemblages from Avicenniamarina leaf litter in a temperate mangrove forest in southeastern Australia. Marine Biology, 142(2): 289-297.

Ha T. T. T., van Dijk H., Bush, S. R., 2012. Mangrove conservation or shrimp farmer's livelihood? The devolution of forest management and benefit sharing in the Mekong Delta, Vietnam. Ocean \& Coastal Management, 69: 185-193.

Hai T. N., 2005. Effects of mangrove leaf litters on the integrated mangrove-shrimp farming systems in $\mathrm{Ca} \mathrm{Mau}$ Province, Vietnam. School of Environment, Resources and Development. Asian Institute of Technology, Thailand.

Hamilton S., 2013. Assessing the role of commercial aquaculture in displacing 
mangrove forest. Bulletin of Marine Science, 89(2): 585-601.

Hodda M., Nicholas W. L., 1985. Meiofauna associated with mangroves in the Hunter River estuary and Fullerton Cove, southeastern Australia. Marine and Freshwater Research, 36(1): 41-50.

Ingels J., Tchesunov A. V., Vanreusel A., 2011. Meiofauna in the Gollum Channels and the Whittard Canyon, Celtic Marginhow local environmental conditions shape nematode structure and function. PLoS One, 6(5): e20094.

Kimmel D. G., Roman M. R., 2004. Longterm trends in mesozooplankton abundance in Chesapeake Bay, USA: influence of freshwater input. Marine Ecology Progress Series, 267: 71-83.

Liu X. S., Xu M., Zhang J. H., Mu G., Liu D., Li X., 2014. Abundance and biomass of deep-sea meiofauna in the northern South China Sea. Journal of Tropical Oceanography, 33(2): 52-59.

Liu X., Xu M., Zhang J., Liu D., Li X., 2015. Community structure and biodiversity of free-living marine nematodes in the northern South China Sea. Acta Oceanologica Sinica, 34(6): 77-85.

Netto S. A., \& Gallucci F., 2003. Meiofauna and macrofauna communities in a mangrove from the Island of Santa Catarina, South Brazil. Hydrobiologia, 505(1-3): 159-170.

Ngo X. Q., Chau N. N., \& Tu N. D., 2013a. Correlation between nematode communities with some environmental parameters in the Dai estuary, Ben Tre. Journal of Biology, 35(3se): 1-7.

Ngo X. Q., Chau, N. N., Nguyen D. T., Pham V. L, Vanreusel A., 2013c. Distribution pattern of free living nematode communities in the eight Mekong estuaries by seasonal factor. Journal Vietnamese Environment, 4(1): 28-33.

Ngo X. Q., Chau, N. N., Smol N., Prozorova L., \& Vanreusel A., 2016. Intertidal nematode communities in the Mekong estuaries of Vietnam and their potential for biomonitoring. Environmental monitoring and assessment, 188(2): 91-106.

Ngo X. Q., Smol N., Vanreusel A., 2013b. The meiofauna distribution in correlation with environmental characteristics in 5 Mekong estuaries, Vietnam. Cahiers de Biologie Marine 54: 71-83.

Ngo X. Q., Vanreusel A., Thanh N. V., Smol N., 2007. Biodiversity of meiofauna in the intertidal Khe Nhan mudflat, Can Gio mangrove forest, Vietnam with special emphasis on free living nematodes. Ocean Science Journal, 42(3): 135-152.

Nguyen V. T., 2007. Fauna of Vietnam. Freeliving nematodes orders Monhysterida, Araeolaimida, Chromadorida, Rhabditida, Enoplida, Mononchida and Dorylaimida. No.22, Science and Technics Publishing House, $455 \mathrm{pp}$.

Pham T. L., Tran T. T., Nguyen T. M. Y., Ngo X. Q., 2017. Phytoplankton community in integrated shrimp-mangrove farming ponds in Ca Mau Province. Proceedings of the $7^{\text {th }}$ National Scientific Conference on Ecology and Biological Resources Hanoi,793-800. (in Vietnamese).

Phan N. H., San H. T., 1993. Mangroves of Vietnam, IUCN Wetlands Programme, Bangkok, Thailand.

Platt H. M., Warwick R. M., 1983. Free-living Marine Nematodes (Part I. British Enoplids). Synopses of the British Fauna No. 28, Linnean Society of London/Estuarine \& Brackish Water Society.

Platt H. M., Warwick R. M., 1988. Free-living Marine Nematodes (Part II. British Chromadorids). Linnean Society of London and the Estuarine and BrackishWater Sciences Association.

Primavera J. H., 2000. Development and conservation of Philippine mangroves: institutional issues. Ecological Economics, 35(1): 91-106. 
Richards D. R., Friess, D. A., 2016. Rates and drivers of mangrove deforestation in Southeast Asia, 2000-2012. Proceedings of the National Academy of Sciences, 113(2): 344-349.

Rzeznik-Orignac J., Fichet D., Boucher G., 2003. Spatio-temporal structure of the nematode assemblages of the Brouage mudflat (Marennes Oléron, France). Estuarine, Coastal and Shelf Science, 58(1): 77-88.

Semprucci F., Balsamo M., 2012. Free-living marine nematodes as bioindicators: past, present and future perspectives. Environmental Research Journal, 6(1): 17-35.

Semprucci F., Moreno M., Sbrocca S., Rocchi M., Albertelli G., Balsamo M., 2013. The nematode assemblage as a tool for the assessment of marine ecological quality status: a case-study in the Central Adriatic Sea. Mediterranean Marine Science, 14(1): 48-57.

Takashima F., 2000. Silvofishery: An aquaculture system harmonized with the environment. In Mangrove-friendly aquaculture: Proceedings of the workshop on mangrove-friendly aquaculture, eds. J. H. Primavera, L. M. B. Garcia, M. T. Castaños, and M. B. Surtida, 13-19. Iloilo City, Philippines: SEAFDEC, Organized by the Aquaculture Department.

Tho N., Ut V. N., Merckx R., 2011. Physicochemical characteristics of the improved extensive shrimp farming system in the Mekong Delta of Vietnam. Aquaculture Research, 42(11): 1600-1614.

Tran T. T., Lam N. L. Q., Quang N. X., Hieu H. H., 2018a. Seasonal and spatial variations of meiofauna communities in correlation to environmental characteristics in the organic shrimp farms of Tam Giang commune, Nam Can district, Ca Mau Province. VNU Journal of Science: Natural Sciences and Technology, 34(1): 55-64.
Tran T. T., Le Q. L. N., Le H. D., Nguyen T. M. Y., Ngo X. Q., 2018b. Intertidal meiofaunal communities in relation to salinity gradients in the Ba Lai river, Vietnam. Journal of Vietnamese Environment, 10(2): 138-150.

Tran T. T., Nguyen T. M. Y., Ngo X. Q., Pham T. L., 2017a. Effect of different water column depths on nematode communities in the mangrove-shrimp farming system, Ca Mau Province, Vietnam Journal of Marine Science and Technology, 17(4A): 269-278.

Tran T. T., Nguyen T. M. Y., Ngo X. Q., Truong T. N., Nguyen N. S., $2017 \mathrm{~b}$. Diversity assessment of benthic macroinvertebrate in shrimp-mangro farming ponds, $\mathrm{Ca}$ Mau Province Proceedings of the $7^{\text {th }}$ national scientific conference on ecology and biological resources. Science and Technics Publishing House. (in Vietnamese).

Tran T. T., Nguyen T. M. Y., Nguyen T., Ngo X. Q., 2017c. Meiofauna in the mangroveshrimp farms ponds, Ca Mau Province. Journal of Science and Technology, 55(3): 271-284.

Tran T. T., Pham T. L., Nguyen T., Ngo X. Q., 2018c. Relationship of free-living nematode communities to some environmental variables in an organic shrimp farms, Ca Mau Province. Journal of Science and Technology, 56(5): 526-648.

Truong T. D., \& Do L. H., 2018. Mangrove forests and aquaculture in the Mekong river delta. Land use policy, 73: 20-28.

Van Diggele, A. D. \& Montagna P. A., 2016. Is salinity variability a benthic disturbance in estuaries? Estuaries and Coasts, 39(4): 967-980.

Vincx M., 1996. Meiofauna in marine and freshwater sediments. In G. S. Hall (Ed.), Methods for the examination of organismal diversity in soils and sediments (pp. 187-195). Wallinfort, UK: $\mathrm{CAB}$ International. 
Vu T. P., 2004. National Report on Mangrove in South China Sea. Vietnam Research Centre for Forest Ecology and Environment, Vietnam.

Warwick R. M., Platt H. M., Somerfield P. J., 1988. Free living marine nematodes (Part III. Monhysterids). The Linnean Society of London and the Estuarine and Coastal Sciences Association, London.

Ysebaert T., Herman, P. M. J., 2002. Spatial and temporal variation in benthic macrofauna and relationships with environmental variables in an estuarine, intertidal soft-sediment environment. Marine Ecology Progress Series, 244: 105-124.

Zeppilli D., Bongiorni L., Cattaneo A., Danovaro R., Santos R. S., 2013. Meiofauna assemblages of the Condor Seamount (North-East Atlantic Ocean) and adjacent deep-sea sediments. Deep Sea Research Part II: Topical Studies in Oceanography, 98: 87-100.

Zullini A., 2005. The Identification manual for freshwater nematode genera, Lecture book, MSc Nematology Ghent University. 